\title{
Oxygenic primary production below the oxycline and its importance for redox dynamics
}

\author{
Andreas Brand $^{1,2} \cdot$ Hannah Bruderer ${ }^{2}$ Kirsten Oswald ${ }^{1,2} \cdot$ Carole Guggenheim $^{1,2}$ • \\ Carsten J. Schubert ${ }^{1} \cdot$ Bernhard Wehrli $^{1,2}$
}

Received: 28 April 2015/Accepted: 12 January 2016/Published online: 25 January 2016

(c) The Author(s) 2016. This article is published with open access at Springerlink.com

\begin{abstract}
We present evidence that oxygenic primary production occurs in the virtually anoxic regions (i.e. regions where no oxygen was detected) of the eutrophic, pre-alpine Lake Rot (Switzerland). Chlorophyll-a measurements in combination with phytoplankton densities indicated the presence of oxygenic primary producers throughout the water column. While Chlorophyceae were present as the main class of oxygenic phototrophs above the oxycline, which extended from 8 down to $9.2 \mathrm{~m}$, the phototrophic community in and below the oxycline was dominated by cyanobacteria. In-situ incubation experiments with $\mathrm{H}^{14} \mathrm{CO}_{3}{ }^{-}$conducted in August 2013 revealed an oxygenic primary production rate of 1.0 and $0.5 \mathrm{mg} \mathrm{C} \mathrm{m}^{-3} \mathrm{~h}^{-1}$ in 9 and $10 \mathrm{~m}$ depth, respectively. However, measurements with optical trace oxygen sensors showed that oxygen concentrations were below the detection limit $\left(20 \mathrm{nmol} \mathrm{l}^{-1}\right)$ during the incubation period below $9.2 \mathrm{~m}$. Potential oxygen consumption rates, which were 10-20 times higher than oxygen production rates, explain this absence of free oxygen. Our data show that oxygen production in the virtually anoxic zone corresponded to approximately $8 \%$ of the oxygen flux driven by the concentration gradient in the oxycline. This provided an important source of electron acceptors for biogeochemical processes beyond the conventional redox boundary and in
\end{abstract}

Andreas Brand

andreas.brand@eawag.ch

1 Department of Surface Waters, Research and Management, Eawag, Swiss Federal Institute of Aquatic Science and Technology, 6047 Kastanienbaum, Switzerland

2 Institute of Biogeochemistry and Pollutant Dynamics, ETH Zurich, 8092 Zurich, Switzerland the apparently oxygen depleted zone of Lake Rot. This oxygenic primary production in the virtually anoxic zone could allow growth and activity of aerobic microorganisms adapted to low oxygen supply.

Keywords Primary production $\cdot$ Anoxic zone $\cdot$ Redox cycling · Oxygen

\section{Introduction}

Oxygen is the most energetic electron acceptor for heterotrophic organisms mineralizing organic matter (Wang and VanCappellen 1996). It also governs the abiotic and biotic re-oxidation of reduced compounds like sulfide, iron and manganese (Canfield et al. 1993) as well as methane (Eller et al. 2005) and controls the nitrification-denitrification dynamics in lakes and sediments (Jensen et al. 1993). Aerobic growth and oxygen respiration can occur at very low oxygen levels with half saturation constants for various heterotrophic organisms below the detection limit of conventional oxygen sensors $(1 \mu \mathrm{M})$ (Lloyd 2002) and as low as $120 \mathrm{nM}$ (Stolper et al. 2010). Until recently, these processes occurring at sub-micromolar oxygen concentrations could not be studied, since the lowermost detection limit for in-situ oxygen sensors was around $1 \mu \mathrm{M}$ (Revsbech et al. 2009; Thamdrup et al. 2012). In the meantime, in-situ sensors with sub-micromolar detection limits have been developed. These sensors comprise Clark-type sensors with typical detection limits of 1-10 nM (Revsbech et al. 2009) as well as optical sensors with a detection limit of $20 \mathrm{nM}$ (Kirf et al. 2014; Klimant et al. 1995). This development allows for profiling across oxic-anoxic interfaces down to sub-micromolar oxygen concentrations (Friedrich et al. 2014; Kirf et al. 2014). 
Aerobic methane oxidation, one of the most important sinks for methane in freshwater systems (Eller et al. 2005; Schubert et al. 2010) is supposed to occur at oxygen concentrations far below micromolar concentrations. Aerobic oxidation of methane is classically observed at the oxicanoxic interface of the water column (Rudd et al. 1976; Schubert et al. 2010), which forms in eutrophic lakes either during the stratification period in holomictic lakes or is permanently present in meromictic lakes. Recent studies indicate that aerobic methane oxidation occurs not only at and above the oxic-anoxic interface, but also in apparently anoxic zones which are virtually oxygen free (Blees et al. 2014; Milucka et al. 2015). We refer to zones with oxygen concentrations below the detection limit of the trace oxygen sensors $\left(20 \mathrm{nmol} \mathrm{l}^{-1}\right)$ as virtually anoxic zones. Recently it has been demonstrated that methane oxidation can be stimulated in anoxic lake waters by light (Milucka et al. 2015; Oswald et al. 2015). This suggests that oxygenic primary production can be a source of electron accepting capacity in virtually anoxic environments, yet this possibility has gone largely unnoticed until now. In lakes with an oxycline close to the water surface, light may still reach below the oxycline and oxygenic photosynthesis could support aerobic processes in these virtually anoxic zones.

It is commonly assumed that the minimum light requirement for oxygenic phototrophic organisms is around $2 \mu \mathrm{E} \mathrm{m}^{-2} \mathrm{~s}^{-1}$ (Raven et al. 2000), yet several studies have shown that the actual requirement can be much lower. Gibson (1985) reported a minimum required photon flux between 0.09 and $0.49 \mu \mathrm{E} \mathrm{m}^{-2} \mathrm{~s}^{-1}$ for active freshwater cyanobacteria, while this threshold can be as low as 0.02 $\mu \mathrm{E} \mathrm{m}^{-2} \mathrm{~s}^{-1}$ in marine systems (Raven et al. 2000). Anoxygenic phototrophs like Chlorobiaceae, which convert sulfide to elemental sulfur, can fix carbon below 0.01 $\mu \mathrm{E} \mathrm{m}^{-2} \mathrm{~s}^{-1}$ (Raven et al. 2000). In-situ studies in eutrophic lakes reported high photoassimilation rates near the oxic-anoxic interface e.g. for Lake Arcas (Camacho and Vicente 1998) or Lake Cadagno (Camacho et al. 2001). Primary production at the oxycline is typically linked with chlorophyll maxima (Camacho 2006) and the phototrophic communities show a sharp layering (Camacho and Vicente 1998). Still, these studies did not report oxygen profiles with sufficient resolution to resolve the oxic-anoxic interface in detail.

Concurrent with the present work, Oswald et al. (2015) found the presence of aerobic methane oxidizers in the anoxic zone of Lake Rot, a highly eutrophic, dimictic lake situated north of Lucerne (Switzerland), while no known groups of anaerobic methane oxidizing archaea were found in the water column. Laboratory incubations with water samples taken from the zone below the oxycline revealed that irradiation with light stimulated methane oxidation significantly, which suggests that methane oxidation in the virtually anoxic water column is tightly coupled to oxygenic primary production. In addition, sulfur bacteria were found regularly far below the oxic-anoxic interface (e.g. Kohler et al. 1984) suggesting that there may also be sufficient light for oxygenic photosynthesis below the oxycline. Both findings motivated the choice of Lake Rot as a promising system to detect in-situ oxygenic primary production below the oxycline. In order to investigate the potential for primary production below the oxycline in the eutrophic Lake Rot we combined in-situ photo-assimilation measurements with the characterization of the phytoplankton community and oxygen measurements at trace levels and high spatial resolution.

\section{Materials and methods}

\section{Study site}

Lake Rot is a $2.4 \mathrm{~km}$ long, $0.4 \mathrm{~km}$ wide pre-alpine, dimictic lake with a maximum depth of $16 \mathrm{~m}$ located north of Lucerne, Switzerland (Bloesch 1974). Due to its wind shielded position, a stable metalimnion, which is typically located at $6-10 \mathrm{~m}$ depth, forms during the stratification period. The lake has undergone a strong anthropogenic eutrophication since the 19th century (Stadelmann 1980). Recovery attempts by increasing freshwater inflow from the Reuss River starting in the 1920s remained unsuccessful (Stadelmann 1980). Only after the construction of an interceptor sewer in 1969 and a sewage treatment plant in 1974, the lake has started to recover slowly (Kohler et al. 1984), but remains eutrophic (Schubert et al. 2010). The onset of stratification typically occurs between March and April (Fig. 7). Due to the eutrophic state of the lake, the hypolimnion becomes anoxic during the first months after the onset of stratification (Fig. 8) and reduced substances like methane and sulfide accumulate in the deep water (Schubert et al. 2010). While methane concentrations increase near the oxic-anoxic interface, the appearance of sulfide does not coincide with the oxycline but is observed deeper in the water column. The separation between the oxycline and the sulfidic zone is caused by Chromatiaceae and Chlorobiaceae which oxidize sulfide phototrophically (Kohler et al. 1984). The oxycline and the sulfide containing zone only coincide at the end of the stratification period (Schubert et al. 2010).

\section{In-situ profiling and sampling campaigns}

Profiles of temperature, conductivity, turbidity and pressure were recorded using a XRX 620 CTD (RBR, Canada), which was connected to our custom made 
profiling and syringe sampling system PIA (profiler for in-situ analyses, Kirf et al. (2014)). Conductivity data were temperature corrected to the specific conductivity at $25^{\circ} \mathrm{C}\left(\mathrm{k}_{25}\right)$. In addition, the system was equipped with needle-type oxygen optodes for oxygen measurements in the range of the oxygen pressure $\mathrm{p}_{\mathrm{O} 2}=0-10^{5} \mathrm{~Pa}$ (PST1, Presens, Germany) and $\mathrm{p}_{\mathrm{O} 2}=0-10^{4} \mathrm{~Pa}$ (TOS7, Presens, Germany). The latter electrode had a detection limit of $1.4 \mathrm{~Pa}$ which correspond to approximately $20 \mathrm{nmol}^{-1}$ (Kirf et al. 2014). The profiler was equipped with a syringe sampler (KC Denmark) which holds $1260 \mathrm{ml}$ syringes. Sampling of each syringe was triggered manually via the online monitoring software written in LabView (National Instruments, USA). In-situ profiles of chlorophyll-a (Chl-a) were recorded using an ECO-FL Fluorescence probe (Wetlabs, USA) with excitation and emission wavelengths $(\mathrm{Ex} / \mathrm{Em})$ of $470 / 695 \mathrm{~nm}$. The Chl-a sensor signal was calibrated with water samples taken at the field site which were analyzed using HPLC. Photosynthetically active radiation (PAR) profiles were recorded using a LI-190 spherical quantum sensor (LI-Cor, USA), while a second quantum sensor logged surface radiation. The fluorescence and the submersible PAR sensors were mounted on a SBE 19 multiparameter probe (Seabird, USA). In order to avoid artifacts like peak smearing and gradient flattening due to the response time of the chemical sensors, profiles were recorded slowly with a vertical profiling velocity of approximately $1.5 \mathrm{~cm} \mathrm{~s}^{-1}$.

Sampling campaigns were conducted on the 5th of June and between the 5th and 7th of August 2013 at the deepest location of Lake Rot (N47_4.251 E8_18.955, WGS84). Table 1 gives an overview of the analyses performed on the different days and the sampling methods used. In June, methane samples were taken from 1 to 6 and 12 to $15 \mathrm{~m}$ at $1 \mathrm{~m}$ resolution and from 6 to $12 \mathrm{~m}$ at $0.5 \mathrm{~m}$ resolution. Samples for phytoplankton density were taken at 5, 7, 8 and $11 \mathrm{~m}$. Both samples were taken using a 51 Niskin bottle (Hydrobios, Germany). Samples for Chl-a containing particle densities were taken at 2 and $4 \mathrm{~m}$ and after every $1 \mathrm{~m}$ down to $14 \mathrm{~m}$ using the syringe sampler. In August, syringe samples were taken in $1 \mathrm{~m}$ steps between 1 and $5 \mathrm{~m}$ and 9-14 $\mathrm{m}$. Between 5 and $9 \mathrm{~m}$ samples were taken in $0.5 \mathrm{~m}$ steps for the determination of Chl-a containing particle densities and chemical analyses with exception of methane. The same depths were chosen for the methane analyses, but samples were taken using a Niskin bottle. The samples for in-situ incubations, laboratory Chl-a measurements and aliquots to quantify phytoplankton were taken at $4,8,9,10,11,12$ and $14 \mathrm{~m}$ depth, also using a Niskin bottle. Due to logistic reasons and time constraints, not all measurements could be done on the same day in August.
Table 1 Analysis and samples taken during the campaigns in 2013

\begin{tabular}{llll}
\hline Day & 5. June & 5. August & 7. August \\
\hline Oxygen & PIA & PIA & PIA \\
Conductivity & PIA & PIA & PIA \\
Temperature & PIA & PIA & PIA \\
Turbidity & PIA & PIA & PIA \\
Sulfide & $\mathrm{S}$ & & $\mathrm{S}$ \\
$\mathrm{CH}_{4}$ & $\mathrm{~N}$ & $\mathrm{~N}$ & \\
$\mathrm{NH}_{4}{ }^{+}$ & & $\mathrm{S}$ & \\
$\mathrm{Fe}^{2+}$ & & $\mathrm{S}$ & \\
$\mathrm{Mn}^{2+}$ & & $\mathrm{S}$ & \\
$\mathrm{NO}_{3}{ }^{-}$ & & $\mathrm{S}$ & \\
Methane oxidation rates & & $\mathrm{N}$ & \\
Chl-a containing particles & $\mathrm{S}$ & & $\mathrm{S}$ \\
Chl-a Profile & $\mathrm{CTD}$ & & $\mathrm{CTD}$ \\
PAR profile & $\mathrm{CTD}$ & & $\mathrm{CTD}$ \\
Surface PAR & & $\mathrm{M}$ & $\mathrm{M}$ \\
Phytoplankton & $\mathrm{N}$ & & $\mathrm{N}$ \\
In-situ primary production & & & $\mathrm{N}$ \\
\hline PIA profies recos & & & \\
\hline
\end{tabular}

PIA profiles recorded in-situ using PIA, $S$ samples taken with the syringe sampler, $N$ samples taken using the Niskin bottle, CTD measurements taken using an additional CTD with submersible PAR sensor and fluorescence probe for Chl-a, $M$ data recorded by a meteorological station

a Details on the laboratory incubations to determine methane oxidation dynamics and their results can be found in Oswald et al. (2015)

\section{Laboratory analyses}

Total sulfide was measured spectrophotometrically using the methylene blue method (Cline 1969). Samples for sulfide analysis were fixed in the field immediately after the sample was taken using zinc acetate solution to prevent loss of sulfide by oxidation and degassing. Dissolved inorganic carbon (DIC) was measured using alkalinity titration following Goltermann et al. (1978) and Rodhe (1958). Chl-a was determined using the rapid HPLC method following the protocol of Murray et al. (1986) using a LiChroCart 250-4 column (Merck, Germany) and a MD2010 Plus diode array detector (Jasco, Germany) with the absorption wavelength of $430 \mathrm{~nm}$. Chl-a containing particles were determined with an Accuri C6 flow cytometer (BD Biosciences, USA) with a fluorescence detector operating at the excitation/emission wavelengths of 488/670 nm which are indicative for Chl-a (Marie et al. 2005). Analyses of nitrate and ammonium were performed using ion chromatography (881 Compact IC pro and 882 Compact IC plus, Metrohm). Dissolved iron and manganese were determined as the fraction smaller than $0.22 \mu \mathrm{m}$ using inductively coupled plasma mass spectrometry ICP-MS (Element2, Thermo-Fisher). Methane 
was determined using headspace gas chromatography using a gas chromatograph with flame ionization detector (Agilent $6890 \mathrm{~N}$, Agilent technologies).

Phytoplankton composition was determined down to the genus level based on the nomenclature published in the Algaebase database (Guiry and Guiry 2013) using light microscopy. Quantitative analyses were performed using the Utermöhl sedimentation technique (Utermöhl 1958).

\section{In-situ incubation}

In-situ primary production (PP) was quantified using the ${ }^{14} \mathrm{C}$ incubation technique (Bossard et al. 2001). Depths for in-situ incubations corresponded to the sampling depths and water was incubated for $4.5 \mathrm{~h}$ from 9:30 am to 2:00 pm on the 7th of August 2015. The depths were chosen to cover various conditions for primary production in Lake Rot. At $4 \mathrm{~m}$ depth, an oxygen, chlorophyll-a and turbidity maximum (Fig. 1c, d) indicated the location of the zone of maximum primary production. The incubation depths 8,9 and $10 \mathrm{~m}$ were chosen to include the transition from oxic to anoxic conditions (Fig. 1c) and $11 \mathrm{~m}$ as PAR was still detected there. The incubations at 12 and $14 \mathrm{~m}$ served as additional controls as light no longer reached these depths. For each incubation, water was filled into $120 \mathrm{ml}$ SchottDuran bottles and $5 \mathrm{mCi} \mathrm{NaH}{ }^{14} \mathrm{CO}_{3}$ was added. In order to distinguish between oxygenic and anoxygenic PP, incubations were conducted with and without addition of $2 \mathrm{ml}$ of $10 \mu \mathrm{M}$ 3-(3,4-dichlorophenyl)-1,1-dimethylurea (DCMU) solution in order to block photosystem II at each depth (Legendre et al. 1983). Incubations in dark bottles with and without addition of DCMU were conducted in 4 and $14 \mathrm{~m}$ depth. All incubations were performed in duplicates. After recovery, the samples were stored in light-proof boxes and brought to the laboratory where primary production was instantaneously determined using the acidic bubbling method following Gachter and Mares (1979). Oxygenic PP was calculated as the difference between the incubations with and without addition of DCMU. Anoxygenic PP was calculated as the difference between the incubations with the addition of DCMU and the average value of all dark incubations.

\section{Correction of in-situ incubations for light contamination}

Even though care was taken to minimize light exposure during the preparation of the incubations on the boat, some exposure to ambient light in the water column could not be prevented during deployment and recovery. In order to correct for the resulting overestimation of oxygenic PP, we used the oxygenic PP in $12 \mathrm{~m}$ depth, where no light was detected, to correct for the light exposure during sample handling using the following equation

$O x P P_{\text {corr }, z}=O x P P_{\text {meas }, z}-\frac{O x P P_{\text {meas }, 12 m}}{C h l-\mathrm{a}_{12 \mathrm{~m}}} C h l-\mathrm{a}_{\mathrm{z}}$

$O x P P_{c o r r, z}$ and $O x P P_{\text {meas }, z}$, are the corrected and measured oxygenic PP rates at depth $z$ in $\left(\mathrm{mg}-\mathrm{C}^{-1} \mathrm{~s}^{-1}\right)$, $O x P P_{\text {meas }, 12 m}$ refers to the measured oxygenic PP at $12 \mathrm{~m}$ and $C h l-a_{12 m}$ and $C h l-a_{z}$ denotes the chlorophyll concentrations in $\left(\mathrm{mg} \mathrm{l}^{-1}\right)$ at $12 \mathrm{~m}$ and $z$ respectively.

\section{Calculation of the PI relationship and estimation of the primary production during the study period}

From the corrected data, we calculated the relationship between the Chl-a specific oxygenic primary production, $P P_{C h l-a}$, which is defined as the ratio between PP in $(\mathrm{g}-\mathrm{C}$ $\left.\mathrm{l}^{-1} \mathrm{~h}^{-1}\right)$ and Chl-a concentration in $\left(\mathrm{g} \mathrm{l}^{-1}\right)$, and the time averaged PAR value during the incubation period as

$P P_{\mathrm{Chl}-\mathrm{a}}=a P A R+b$

where $P A R$ is given in $\left(\mu \mathrm{E} \mathrm{m}^{-2} \mathrm{~s}^{-1}\right)$. The regression parameters $a$ and $b$ were determined as $a=0.0133 \mathrm{~g}-\mathrm{C}$ g-Chl-a ${ }^{-1} \mathrm{~m}^{2} \mathrm{~s} \mathrm{~h}^{-1} \mu \mathrm{E}^{-1}$ and $b=0.017 \mathrm{~g}-\mathrm{C} \mathrm{g}-\mathrm{Chl}-\mathrm{a}^{-1} \mathrm{~h}^{-1}$ with a correlation coefficient of $\mathrm{R}^{2}=0.997$. The primary production rate for the 5th of August was calculated based on the relationship described by Eq. 2, the PAR profile normalized by the surface radiation recorded on the 7th of August (Fig. 1d) and the surface radiation recorded on the 5th of August (Fig. 2a).

\section{Results}

\section{Physical parameters}

During the field campaigns in June as well as in August, the lake was thermally stratified. A maximum temperature gradient of $3{ }^{\circ} \mathrm{C} \mathrm{m}^{-1}$ was observed between 5 and $6.3 \mathrm{~m}$ in June while thermal stratification was higher in August with a maximum gradient of $3.9^{\circ} \mathrm{C} \mathrm{m}^{-1}$ located between 3.6 and $6.2 \mathrm{~m}$ depth (Fig. 1a, c). An increase in $\mathrm{k}_{25}$ from $350 \mu \mathrm{S} \mathrm{cm}{ }^{-1}$ in the hypolimnion in June to $380 \mu \mathrm{S} \mathrm{cm}^{-1}$ in August reflected the accumulation of carbonates, nutrients and reduced substances resulting from the mineralization of organic matter in the lower zones of the lake. The steepest gradients in $\mathrm{k}_{25}$ were observed between 5 and $7 \mathrm{~m}$ in June and 4-6 $\mathrm{m}$ in August. These locations coincide with the oxygen maxima in the lake (Fig. 1) suggesting that the gradient in $\mathrm{k}_{25}$ is due to the uptake of nutrients by phototrophic organisms. PAR was detectable throughout the water column in June but only down to $11 \mathrm{~m}$ in August. 
(a) Total Sulfide $\left[\mu \mathrm{mol} \mathrm{I}^{-1}\right]$, Oxygen $\left[\mu \mathrm{mol} \mathrm{I}^{-1}\right]$, Methane $\left[\mu \mathrm{mol} \mathrm{I}^{-1}\right]$, Conductivity $\left[\mu \mathrm{S} \mathrm{cm}^{-1}\right]$

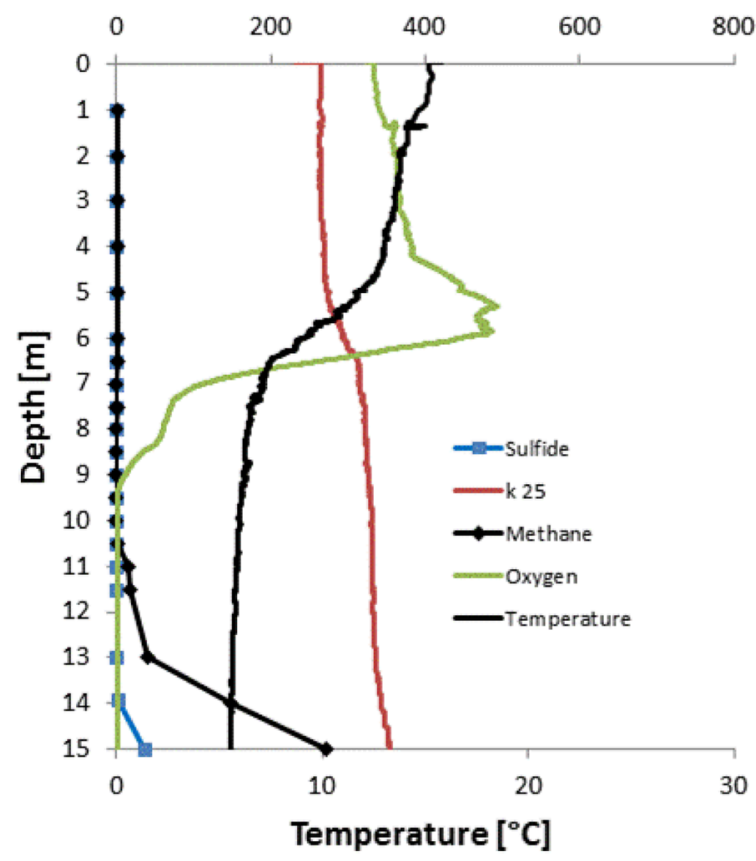

(c) Total Sulfide $\left[\mu \mathrm{moll}^{-1}\right]$, Oxygen $\left[\mu \mathrm{mol} \mathrm{I}^{-1}\right]$, Methane $\left[\mu \mathrm{mol} \mathrm{I}^{-1}\right]$, Conductivity $\left[\mu \mathrm{S} \mathrm{cm}^{-1}\right]$

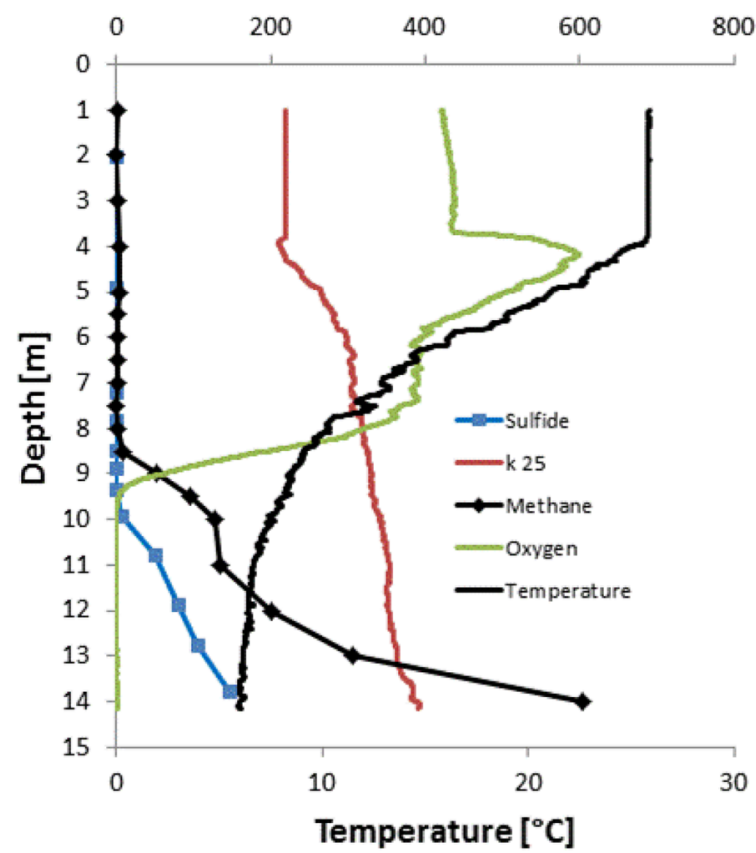

(b) Particle counts $\left[10^{6} \mathrm{I}^{-1}\right]$, Turbidity [NTU], $\mathrm{Chl}-\mathrm{a}\left[\mu \mathrm{g} \mathrm{I}^{-1}\right]$

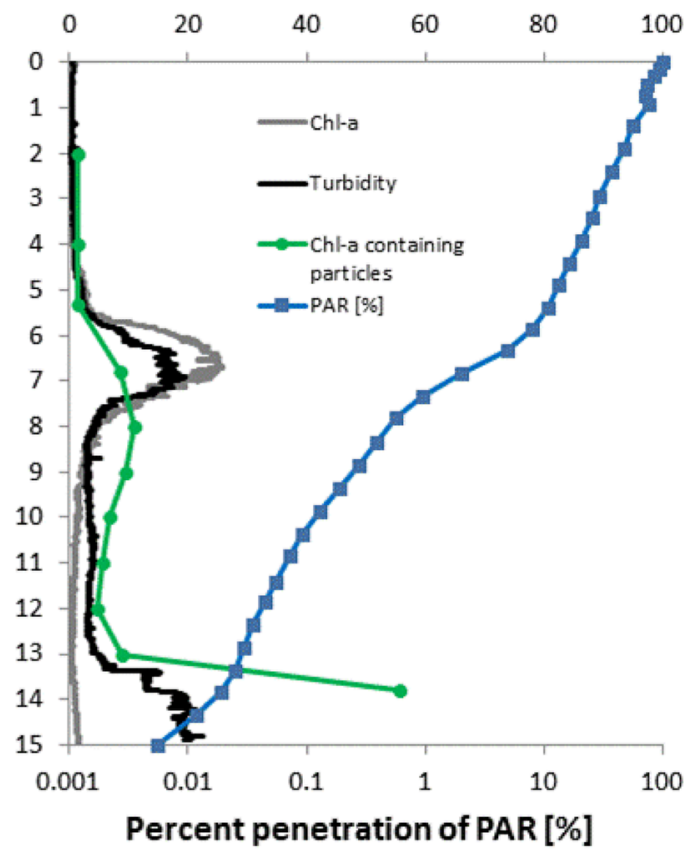

(d) Particle counts $\left[10^{7} \mathrm{I}^{-1}\right]$, Turbidity [NTU], $\mathrm{Chl}-\mathrm{a}\left[\mu \mathrm{gl}^{-1}\right]$

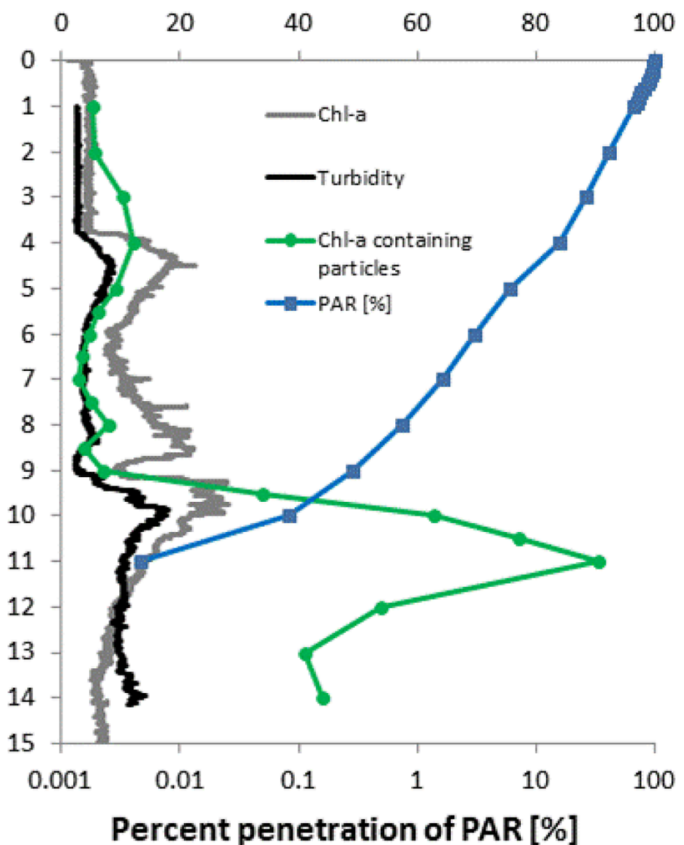

Fig. 1 Water column profiles recorded in June (a, b) and August 2013 (c, d). All data shown in $\mathbf{c}$ and $\mathbf{d}$ besides methane were measured on the 7 th of August. Sulfide denotes total sulfide concentration, $\mathrm{k}_{25}$ the specific conductivity calculated for $25^{\circ} \mathrm{C}$ 


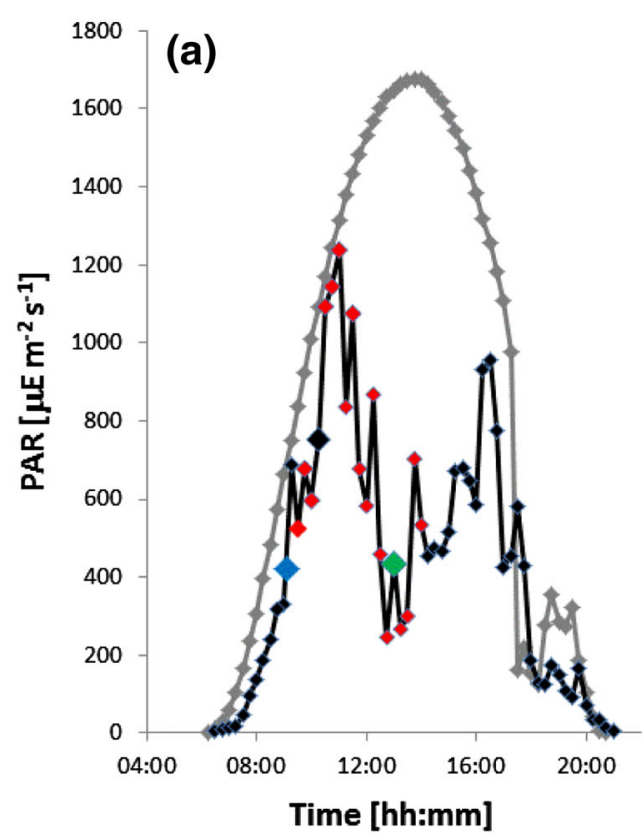

Fig. 2 a Surface radiation on the 5th (grey line with diamonds) and 7th of August (black line). Small red diamonds denote the incubation period, the large blue diamond denotes the time when the PAR profile in $\mathbf{b}$ was taken, the green and the large black diamond denote the times when oxygen profiles shown in $\mathbf{c}$ were taken. b PAR profile

$0.1 \%$ of the surface radiation was still available at $10 \mathrm{~m}$ depth during both campaigns (Fig. 1b, d).

\section{Redox active components}

Oxygen profiles exhibited distinct maxima of more than $400 \mu \mathrm{mol} 1^{-1}$ at the upper end of the zone of maximal thermal stratification indicating intense photosynthetic activity (Fig. 1a, c). In June, the maximum value was $480 \mu \mathrm{mol} 1^{-1}$ corresponding to a 1.4 fold oversaturation. In August the value was even higher at $590 \mu \mathrm{mol} \mathrm{l}^{-1}$ which corresponded to a 2.3-fold oversaturation. During both campaigns two distinct zones of oxygen decrease were observed from the oxygen profiles. The first zone started right below the oxygen maximum and extended down to $7.2 \mathrm{~m}$ in June and $6 \mathrm{~m}$ in August. The second zone started at approximately $8 \mathrm{~m}$ and the oxygen detection limit was reached below $9.2 \mathrm{~m}$ during both campaigns (Fig. 1a, c). Total sulfide was detected only in June in the lowermost sample taken from $15 \mathrm{~m}$ depth, while sulfide was detected in August starting at $10 \mathrm{~m}$ depth and increasing almost linearly up to $145 \mu \mathrm{mol}^{-1}$ at $14 \mathrm{~m}$ depth (Fig. 1a, c). Methane concentrations were three times higher at $14 \mathrm{~m}$ in August $\left(604 \mu \mathrm{mol} \mathrm{l}^{-1}\right)$ than in June $\left(149 \mu \mathrm{mol} \mathrm{l}^{-1}\right)$. In August, methane concentrations already increased significantly below $8 \mathrm{~m}$ depth in the oxic zone, while this increase was only observed below the oxycline at $10.5 \mathrm{~m}$ in

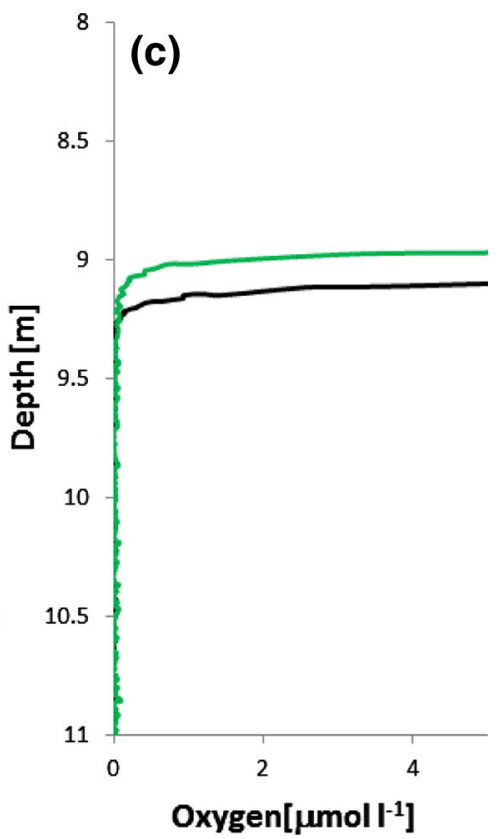

taken during the incubation experiment. PAR values for the depths between 8 and $11 \mathrm{~m}$ are shown as numbers for clarity. c Trace oxygen profiles recorded during the incubation (black line first profile, green line 2nd profile)

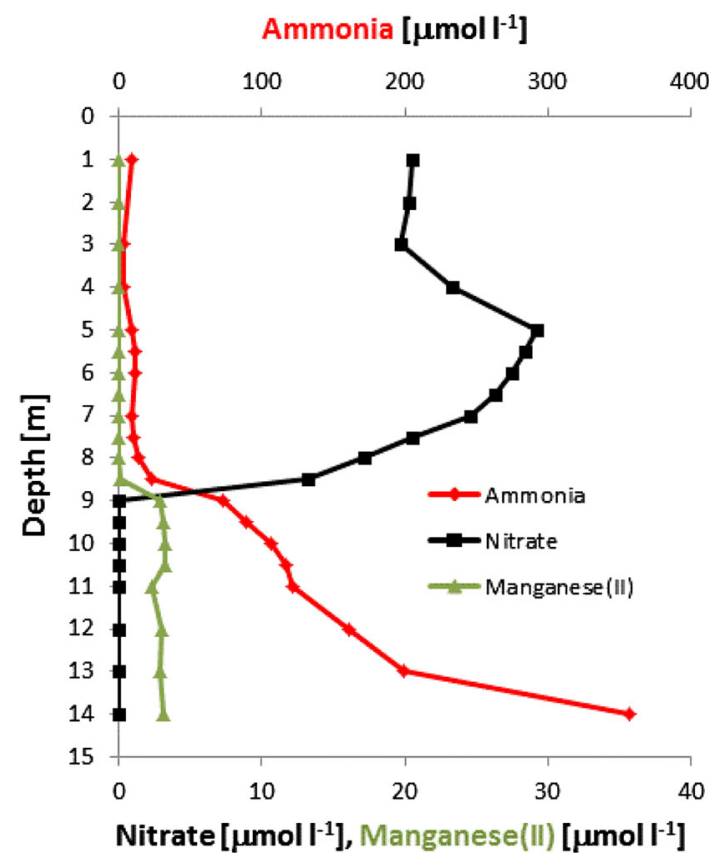

Fig. 3 Ammonia, nitrate and manganese(II) profiles measured in August 2013. The concentration of iron(II) was below $0.5 \mu \mathrm{mol} 1^{-1}$ throughout the profile

June. Maximum nitrate concentrations were around $29 \mu \mathrm{mol} \mathrm{l}^{-1}$ at $6 \mathrm{~m}$ depth and no longer detected below $9 \mathrm{~m}$ (Fig. 3). Maximum ammonium concentrations of 
$360 \mu \mathrm{mol} \mathrm{l}{ }^{-1}$ were found at $14 \mathrm{~m}$ depth with a steep decrease down to $14 \mu \mathrm{mol} \mathrm{l}^{-1}$ at $8 \mathrm{~m}$. Low ammonium concentrations were detected in the major part of the oxic zone (Fig. 3). Manganese(II) concentrations were around $3 \mu \mathrm{mol} \mathrm{l}^{-1}$ below $8.5 \mathrm{~m}$ (Fig. 3), while iron(II) was detected below $10 \mathrm{~m}$, but never exceeded $0.5 \mu \mathrm{mol}^{-1}$.

\section{Turbidity and chlorophyll a}

In June, turbidity maxima were observed between 6.5 and $7.5 \mathrm{~m}$ (Fig. 1b) and another steep increase was observed at $13.5 \mathrm{~m}$ depth right on top of the sulfidic zone (Fig. 1a). In August, an upper turbidity maximum was located at $4.5 \mathrm{~m}$, which coincided with the oxygen maximum, while a lower maximum was observed at $10 \mathrm{~m}$ depth on top of the sulfidic zone (Fig. 1d). The number of Chl-a containing particles identified by the red fluorescence with the flow cytometer showed a maximum of $11 \times 10^{6}$ counts $1^{-1}$ at $8 \mathrm{~m}$ depth in June and of $12 \times 10^{7}$ counts $1^{-1}$ at $4 \mathrm{~m}$ depth in August close to the location of the turbidity maximum. A significantly larger maximum of Chl-a containing particles was found in the lower turbidity maximum with $55 \times 10^{6}$ particles in June and $96 \times 10^{7}$ in August (Fig. 1b, d). In general, the number of Chl-a containing particles was approximately tenfold higher in August. Turbidity peaks also coincided with peaks observed by the Chl-a in-situ probes (Fig. 1b, d). Maximum Chl-a concentrations were around $25 \mu \mathrm{g} 1^{-1}$ during both campaigns and corresponded with the location of the oxycline. While only one distinct peak at $7 \mathrm{~m}$ was observed in June, several peaks were visible in August with maxima at $4.5,8.5$ and $9.5 \mathrm{~m}$ suggesting several accumulation zones for different phototrophic organisms.

\section{Distribution of primary producers}

The different accumulation zones in August were characterized by a variable composition of the phototrophic community (Fig. 4b). The change in community composition between June (Fig. 4a) and August (Fig. 4b) also indicates a high temporal variability. Cyanophyceae were the dominant class of primary producers below $8 \mathrm{~m}$ in June as well in August with maxima of $4 \times 10^{7}$ counts $1^{-1}$ at $8 \mathrm{~m}$ in June and $7 \times 10^{7}$ counts $1^{-1}$ at $11 \mathrm{~m}$ in August (Fig. $4 \mathrm{a}, \mathrm{b}$ ). In the epilimnetic oxygen maximum Bacillariophyceae and Cya-

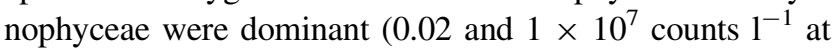
$5 \mathrm{~m}$ respectively) (Fig. 4a) in June, whereas in August a clear dominance of Chlorophyceae was observed $\left(3 \times 10^{7}\right.$ counts $1^{-1}$ at $4 \mathrm{~m}$ ) (Fig. $4 \mathrm{~b}$ ). In the sulfidic zone, phototrophic sulfur bacteria (Chlorobiaceae) were observed in August but not in June (Fig. 4a, b). Chlorobiaceae and Cyanophyceae coexisted in the sulfidic zone with Cyanophyceae being the dominant class above $14 \mathrm{~m}$. While Planktothrix was the only clearly dominant genus at $8 \mathrm{~m}$ in
June, Plankthotrix, Phormidium and Synecoccocus were the most abundant genera in August in the region below $9 \mathrm{~m}$. A detailed list of the genera present in the water column can be found in Tables 4 and 5 in the "Appendix".

\section{Primary production estimates}

Incubation experiments were conducted on the 7th of August which was a cloudy day with a significantly lower surface irradiance compared to a day without cloud cover (Fig. 2a). While recording the PAR profile, surface irradiance was around $400 \mu \mathrm{E} \mathrm{m}^{-2} \mathrm{~s}^{-1}$ and values in the water column between 9 and $11 \mathrm{~m}$ ranged from 1.2 to $0.02 \mu \mathrm{E}$ $\mathrm{m}^{-2} \mathrm{~s}^{-1}$ (Fig. 2b). During the incubation time surface PAR was in the range of 245 and $1240 \mu \mathrm{E} \mathrm{s}^{-1}$ with a time averaged value of $670 \mu \mathrm{E} \mathrm{m}^{-2} \mathrm{~s}^{-1}$ (Fig. 2a). From the averaged surface PAR and the relative PAR profile (Fig. 1b) we can calculate a time averaged PAR of 1.9 and $0.54 \mu \mathrm{E} \mathrm{m}^{-2} \mathrm{~s}^{-1}$ at 9 and $10 \mathrm{~m}$ depth, respectively.

Incubation experiments at $4 \mathrm{~m}$ depth resulted in a corrected oxygenic PP of $29.2 \pm 1.8 \mathrm{mg} \mathrm{C} \mathrm{m}^{-3} \mathrm{~h}^{-1}$. At the depths from 8 to $14 \mathrm{~m}$ corrected oxygenic PP decreased continuously from $1.87 \pm 0.18 \mathrm{mg} \mathrm{C} \mathrm{m}^{-3} \mathrm{~h}^{-1}$ to zero at $11 \mathrm{~m}$ depth (blue bars in Fig. 5). At 9 and 10 m, oxygenic PP rates corrected for light contamination were $1.04 \pm 0.04,0.43 \pm 0.07 \mathrm{mg} \mathrm{C} \mathrm{m}{ }^{-3} \mathrm{~h}^{-1}$ (blue bars in Fig. 5). On average, uncorrected oxygenic PP rates were higher by $0.28 \mathrm{mg} \mathrm{C} \mathrm{m}^{-3} \mathrm{~h}^{-1}$ (red bars in Fig. 5). The anoxygenic PP increased from $0.18 \pm 0.10$ to $1.3 \pm 0.05 \mathrm{mg} \mathrm{C} \mathrm{m}^{-3} \mathrm{~h}^{-1}$ (Fig. 5). Since anoxygenic PP was not the central part of our study, it was not corrected for light contamination and thus only shows that it could occur down to $14 \mathrm{~m}$ if light was present. The average dark assimilation rate was $0.37 \pm 0.13 \mathrm{mg} \mathrm{C} \mathrm{m}^{-3} \mathrm{~h}^{-1}$, while the dark assimilation at $4 \mathrm{~m}$ was slightly lower $\left(0.26 \pm 0.09 \mathrm{mg} \mathrm{C} \mathrm{m}^{-3} \mathrm{~h}^{-1}\right)$ than at $14 \mathrm{~m}$ depth $\left(0.48 \pm 0.03 \mathrm{mg} \mathrm{C} \mathrm{m}^{-3} \mathrm{~h}^{-1}\right)$. The oxygenic PP normalized by the Chl-a concentration shows a linear increase with PAR (Fig. 6), which does not level off. Two oxygen profiles recorded in-situ at the beginning and at the end of the incubations using trace oxygen electrodes did not show the formation of free oxygen below $9.2 \mathrm{~m}$ (Fig. 2c) and the differences in the location of the profiles were most likely due to internal water movement.

\section{Discussion}

\section{Zonation of primary producers}

The distribution of primary producers during our field campaign followed the typical patterns which have also been observed in other studies on aquatic systems 
Density Cyanophyceae $\left[10^{7}\right.$ Cells $\left.\mathrm{I}^{-1}\right]$

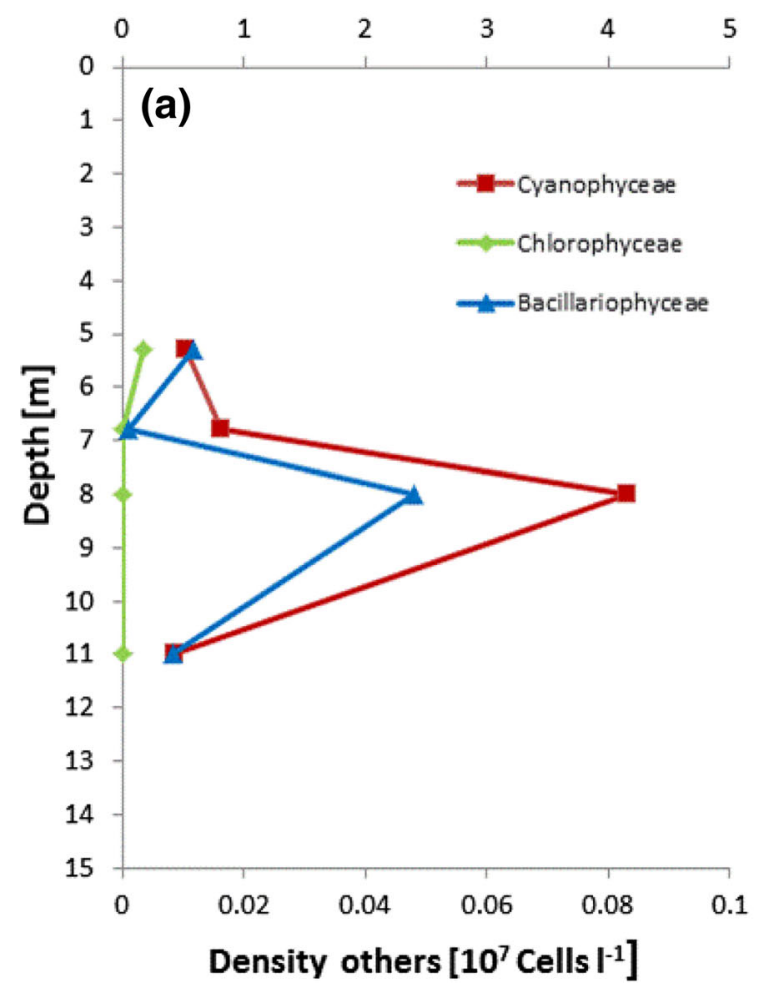

Density $\left[10^{7}\right.$ Cells $\left.^{-1}\right]$

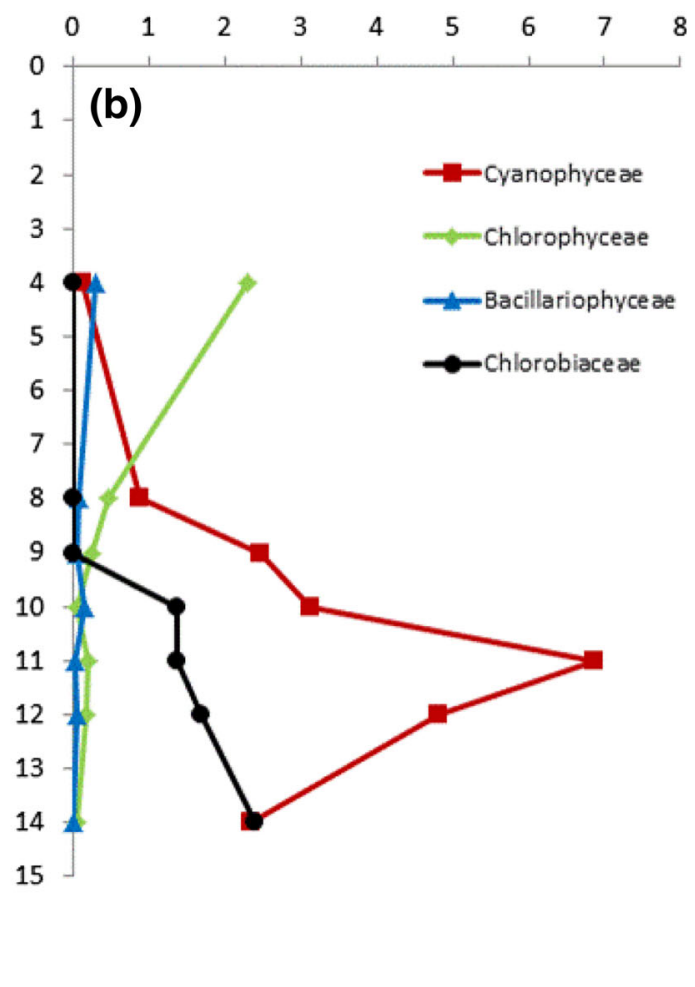

Fig. 4 Densities of dominant phototrophic organism classes. a 5th of June 2014 and b 7th of August. No Chlorobiaceae were found in June

exhibiting sulfidic zones. These studies comprise lakes (Camacho 2006; Camacho et al. 2001), oceans (Overmann and Manske 2006) as well as microbial mats (Stal 1995). While Chlorophyceae constituted a major part of primary producers in August at the top of the epilimnion, Cyanophyceae were the main oxygenic phototrophs below $8 \mathrm{~m}$ during both campaigns (Fig. 4). Cyanophyceae were also the dominant class in June above $8 \mathrm{~m}$. During the August campaign, the maximum concentration of Cyanophyceae was observed between 10 and $11 \mathrm{~m}$ depth. The Cyanophyceae community was dominated by the genera Plankthotrix, Phormidium and Synecoccocus in June as well as in August (Tables 4, 5). All these genera contain species which are sulfide tolerant (Camacho et al. 2000; Cohen et al. 1986; Ward et al. 2012) and are capable of living under low light conditions (Camacho et al. 1996). The distinct pattern of phytoplankton in August with Chlorophyceae being the dominant class at $4 \mathrm{~m}$ depth and a maximum cell density of Cyanophyceae at $11 \mathrm{~m}$ (Fig. 4b) suggests that phytoplankton observed below the oxycline did not stem from settling from the upper zones of Lake Rot. In addition, the low values of turbidity, Chl-a and Chla containing particles above $4 \mathrm{~m}$ suggests that algal growth at the surface of lake Rot was low compared to the growth in deeper zones.

\section{Phototrophy under low light conditions in Lake Rot}

We estimated the quantum efficiency by calculating the ratio between assimilated $\mathrm{C}$ during incubation and the absorbed light quanta. The values ranged between $0.014 \mathrm{~mol} \mathrm{E}^{-1}$ at $8 \mathrm{~m}$ and $0.020 \mathrm{~mol} \mathrm{E}^{-1}$ at $10 \mathrm{~m}$ depth. Since we did not correct for the absorbance of light by particles other than phototrophic organisms, our calculated estimate represents a lower limit of quantum efficiency. Still, our values agree well with the values reported in other studies for cyanobacteria in the laboratory $\left(0.03 \mathrm{~mol} \mathrm{E}^{-1}\right.$, Oren et al. 1977) and algae in the field (0.003-0.052 mol $\mathrm{E}^{-1}$, Fahnenstiel et al. 1984; Kirk 1994). Since we performed the in-situ incubations under very low light conditions in Lake Rot, we only obtained the initial, linear part of the P-I relation (Fig. 6) with a slope of $0.0133 \mathrm{~g}-\mathrm{C}$ (gChl-a $)^{-1} \mathrm{~h}^{-1}\left(\mu \mathrm{E} \mathrm{m}^{-2} \mathrm{~s}^{-1}\right)^{-1}$, which corresponds to $3.6 \times 10^{-6} \mathrm{~g}-\mathrm{C}(\mathrm{g}-\mathrm{Chl}-\mathrm{a})^{-1}\left(\mathrm{E} \mathrm{m}^{-2}\right)^{-1}$, a value which is well in the range of various other studies (see MacIntyre et al. 2002 for an extensive review).

Our incubation experiments in August support that oxygenic PP took place below the oxycline of Lake Rot. This result clearly indicates that the phototrophic organisms were active in the virtually anoxic zone. The uncorrected oxygenic as well as the anoxygenic PP rates 


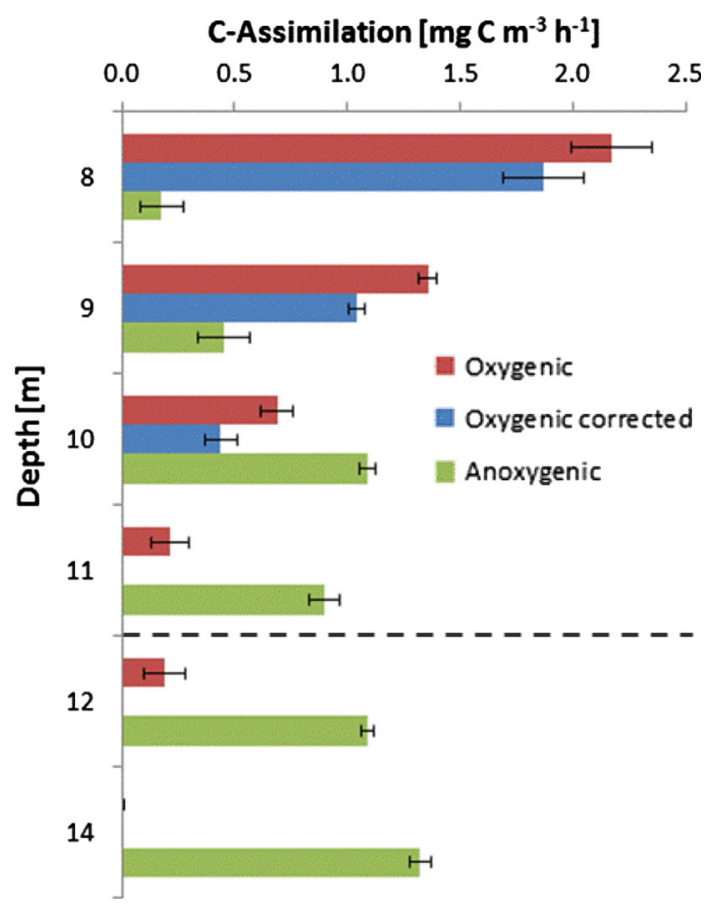

Fig. 5 Results of ${ }^{14} \mathrm{C}$ incubation experiment conducted on the 7 th of August. The potential artifact induced by unavoidable light exposure during deployment and retrieval was likely responsible for the oxygenic assimilation in the absence of PAR below $10 \mathrm{~m}$ (red bars). Blue bars show the assimilation rates corrected for this effect. The dashed black line indicates the boundary below which no light was detected

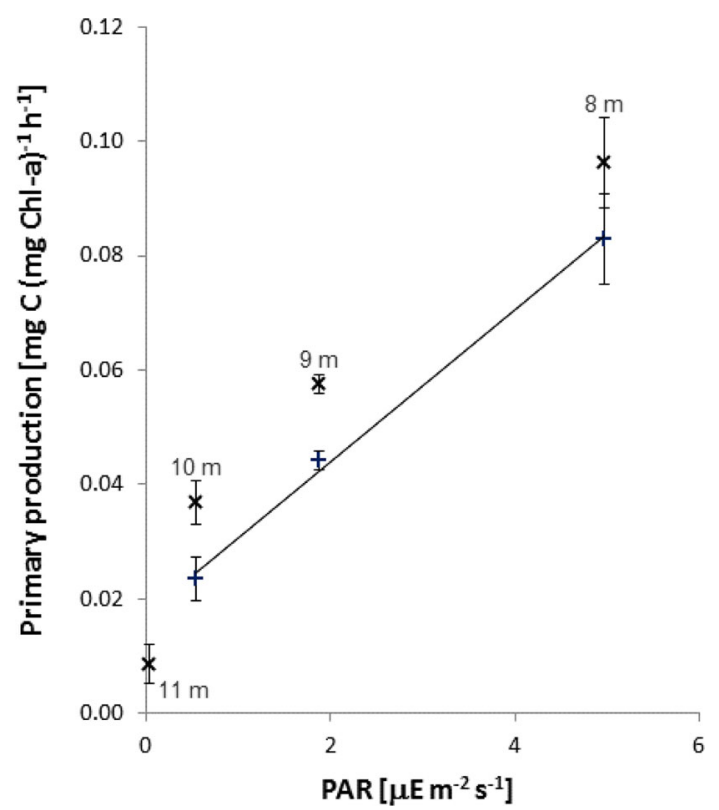

Fig. 6 Chl-a specific oxygenic primary production as a function of PAR. $x$ denotes measured values and + values corrected for light exposure during sample handling. The regression line denotes the linear fit to the corrected data indicate that primary producers in the aphotic zone are still capable of PP in the presence of light. This potential for oxygenic PP was also confirmed by Oswald et al. (2015) who observed a strong stimulation of methane oxidation in samples taken between 9 and $11 \mathrm{~m}$ on the 5 th of August when they were irradiated by light in the laboratory (see their Fig. 3). Even though we only measured PP directly in August, recorded profiles of Chl-a in combination with the PAR profiles (Fig. 1b) suggest that oxygenic primary production could have taken place in the hypolimnion also during the June campaign, when $0.01 \%$ of the surface PAR light penetrated down to $14 \mathrm{~m}$ and sulfide was only detectable at $15 \mathrm{~m}$ depth (Fig. 1a, b). The change in phytoplankton composition between the two field campaigns precluded a quantitative extrapolation of the measured PP values. The much lower number of Cyanophyceae cells below the oxycline (Fig. 4) suggested that the primary production rates were probably lower in June.

\section{Oxygenic PP and the absence of oxygen}

Our measurements support that oxygenic primary production was occurring in zones where no oxygen was measured. Our trace electrodes with detection limits of $20 \mathrm{nmol}^{-1}$ indicated oxygen free conditions during the incubation period below $9.5 \mathrm{~m}$ even though ${ }^{14} \mathrm{C}$ uptake clearly showed that oxygenic PP took place (Figs. 2c, 5). Very fast consumption by i.e. the oxidation of methane, ammonium and organic carbon could explain the absence of oxygen in these zones. High ammonium $\left(>300 \mu \mathrm{mol} \mathrm{l}^{-1}\right.$, Fig. 3) and methane $\left(>600 \mu \mathrm{mol} \mathrm{1}{ }^{-1}\right.$, Fig. 1c) concentrations in August indicate that there was a high potential oxygen demand, while the contributions of iron and manganese were negligible (Fig. 3). In addition, Oswald et al. (2015) found aerobic methane oxidizing bacteria close above and below the oxycline $\left(>10^{7}\right.$ cells $1^{-1}$ of aerobic gammaproteobacterial methanotrophs between 9 and $11 \mathrm{~m}$ ). In line with the incubation experiments under light irradiation, Oswald et al. (2015) performed incubation experiments also under dark conditions with the addition of oxygen. In these experiments, oxygen was added to a final concentration of $15 \mu \mathrm{mol} 1^{-1}$ to the samples, and no methane oxidation occurred after $12 \mathrm{~h}$, suggesting that all the oxygen had been consumed by that time (see their Fig. 3b). Based on this result we can estimate the potential rate of oxygen consumption as $1.25 \mathrm{mmol} \mathrm{m}^{-3} \mathrm{~h}^{-1}$, which is about 10 times higher than the oxygen generation by primary production at $9 \mathrm{~m}\left(0.11 \mathrm{mmol} \mathrm{m}^{-3} \mathrm{~h}^{-1}\right)$ and 20 times higher than the oxygen generation at $10 \mathrm{~m}$ $\left(0.05 \mathrm{mmol} \mathrm{m}^{-3} \mathrm{~h}^{-1}\right)$. 


\section{Relevance of oxygenic PP below the oxycline for redox dynamics}

In order to assess the relevance of the primary production close to and below the oxycline, we estimated the daily oxygenic PP for the 7th of August and the 5th of August, an almost fully sunny day (Fig. 2a; Table 2). The estimates were based on the PI relationship (Eq. 2; Fig. 6), the surface PAR data (Fig. 2a) and the relative PAR profile (Fig. 1d). Depth profiles of turbidity and oxygen measured on the 7th of August (Fig. 1c, d) and on the 5th of August (Fig. 8) were nearly identical suggesting that the relative light penetration as well as the distribution of particles and primary producers were similar on both days. Oxygenic PP was $28 \%$ lower on the 7 th of August compared to the 5th of August. On both days, the daily oxygenic PP at $10 \mathrm{~m}$ was on average $54 \%$ lower than the oxygenic PP at $9 \mathrm{~m}$ due to the strong light attenuation. The depth integrated oxygenic PP from 9 to $10 \mathrm{~m}$ was between $1.5 \mathrm{mmol} \mathrm{m}^{-2}$ $\mathrm{day}^{-1}$ for the 7th of August and $2.04 \mathrm{mmol} \mathrm{m}^{-2} \mathrm{day}^{-1}$ for the 5th of August.

If we assume a stoichiometry of $1: 1$ for the release of oxygen, this corresponds to the production of 6-8.4 mmol $\mathrm{e}^{-} \mathrm{m}^{-2}$ of electron accepting capacity per day. Oswald et al. (2015) calculated an electron balance for Lake Rot on the 5th of August. The contribution of the individual redox active components considered is shown in Table 3. They found that the flux of total electron accepting capacity was $113 \mathrm{mmol} \mathrm{e} \mathrm{e}^{-} \mathrm{m}^{-2} \mathrm{day}^{-1}$. Of these, $105 \mathrm{mmol} \mathrm{e}^{-} \mathrm{m}^{-2}$ day $^{-1}$ were due to oxygen and $8 \mathrm{mmol} \mathrm{e}^{-} \mathrm{m}^{-2}$ day $^{-1}$ due to nitrate. The flux of reductants was $123 \mathrm{mmol} \mathrm{e}^{-} \mathrm{m}^{-2}$ day $^{-1}$ mainly due to ammonium and methane (Table 3 ), resulting in a gap of $10 \mathrm{mmol} \mathrm{e}^{-} \mathrm{m}^{-2}$ day $^{-1}$ of electron accepting capacity. Even though there is a high uncertainty in the methane flux (Table 3), Oswald et al. (2015) claim that this gap is very likely an underestimation, since dissolved organic matter was not considered as an additional potential electron donor in the balance. Similar gaps in the electron balance were reported by Schubert et al. (2010). In June 2007 they observed fluxes of 46 and $52 \mathrm{mmol} \mathrm{e} \mathrm{m}^{-2}$ day $^{-1}$ of main electron acceptors and reductants, respectively resulting in a gap of $6 \mathrm{mmol} \mathrm{\textrm {e } ^ { - }}$ $\mathrm{m}^{-2} \mathrm{day}^{-1}$. This highlights the fact that such imbalances in the fluxes of electron acceptors and donors occur frequently in the investigated lake. Our measurements suggest that oxygenic PP in the virtually anoxic zone, which corresponded to $8 \%$ of the oxygen flux driven by the concentration gradient in the oxycline in our study can partly close the observed gaps in electron balances. In addition, during our study oxygenic primary production in the virtually anoxic zone was an equally important source of electron accepting capacity as the flux of nitrate $(8 \mathrm{mmol}$ $\mathrm{e}^{-} \mathrm{m}^{-2}$ day $\left.^{-1}\right)$.

In addition to their laboratory incubations in August, Oswald et al. (2015) observed $\delta^{13} \mathrm{C}$ profiles of methane in Lake Rot which suggested that methane oxidation indeed occurred in the anoxic zone below the oxycline down to $10 \mathrm{~m}$ and thus also in the virtually anoxic zone. As mentioned above, aerobic methane oxidizing bacteria were found in these zones, while anaerobic methane oxidizing archaea were absent throughout the water column (Oswald et al. 2015). Our in-situ study shows that even under relatively low light conditions oxygenic PP is most likely fueling this methane oxidation even though no oxygen is detectable by state of the art oxygen trace electrodes. Our study provides quantitative evidence that oxygenic primary production at the oxycline contributes significantly to the redox balance between electron acceptors and reduced substances. Incubation experiments in the laboratory performed in August 2012 on methane oxidation also showed a stimulation by light (Oswald et al. 2015) suggesting that oxygenic PP in the virtually

Table 2 Total surface PAR and estimated primary production over 1 day (14.75 daylight hours) close to and below the oxycline

\begin{tabular}{|c|c|c|c|c|}
\hline Day & Total surface PAR $\left(\mathrm{E} \mathrm{m}^{-2} \mathrm{day}^{-1}\right)$ & PP $9 \mathrm{~m}\left(\mathrm{mmol} \mathrm{m}^{-2} \mathrm{day}^{-1}\right)$ & PP $10 \mathrm{~m}\left(\mathrm{mmol} \mathrm{m}^{-2} \mathrm{day}^{-1}\right)$ & PP 9-10 m (mmol m ${ }^{-2}$ day $\left.^{-1}\right)$ \\
\hline 05. Aug & 22.9 & 1.43 & 0.61 & 2.04 \\
\hline 07. Aug & 46.0 & 0.97 & 0.50 & 1.47 \\
\hline
\end{tabular}

Table 3 Electron fluxes of the individual redox active components considered in the electron balance of Oswald et al. (2015)

\begin{tabular}{llllll}
\hline Component & $\mathrm{O}_{2}$ & $\mathrm{NO}_{3}^{-}$ & $\mathrm{CH}_{4}$ & $\mathrm{NH}_{4}^{+}$ & $\mathrm{Mn}^{2+}$ \\
\hline Flux $(\mathrm{mmol} \mathrm{e}$ & & & \\
\hline
\end{tabular}

Note that sulfide was not considered in the balance since it is oxidized by anoxygenic phototrophs 
anoxic zone may be a regularly occurring phenomenon in Lake Rot.

\section{Conclusions}

Our study shows that oxygenic PP can also occur in the anoxic zones of the hypolimnion in a lake in which the oxycline is situated above the aphotic zone. The fact that oxygen was not detected using trace oxygen electrodes while oxygenic PP occurred suggests that the consumption of the produced oxygen was very fast and prevented the formation of measurable free oxygen. The rate of oxygenic PP in the anoxic hypolimnion corresponds to about $8 \%$ of the oxygen flux downwards across the oxycline. Even though this process does not constitute the major oxygen source for the overall electron budget in the lake, it can fuel aerobic processes and enable the survival and growth of aerobic organisms in the virtually oxygen free hypolimnion. We expect that this effect is important in other lakes with a shallow oxycline, since recent studies showed that organisms adapted to low oxygen conditions can maintain a high respiration activity even under very low oxygen concentrations (Stolper et al. 2010).

Acknowledgments We thank Christian Dinkel for the help in the field, Daniel Steiner for the ${ }^{14} \mathrm{C}$ measurements and support during the in-situ incubation measurements and Regula Illi for the phytoplankton counts. This work was funded by the Swiss National Science Foundation (Grants 135299 and 153091) and by Eawag.

Open Access This article is distributed under the terms of the Creative Commons Attribution 4.0 International License (http://crea tivecommons.org/licenses/by/4.0/), which permits unrestricted use, distribution, and reproduction in any medium, provided you give appropriate credit to the original author(s) and the source, provide a link to the Creative Commons license, and indicate if changes were made.

\section{Appendix}

See Figs. 7, 8; Tables 4, 5.
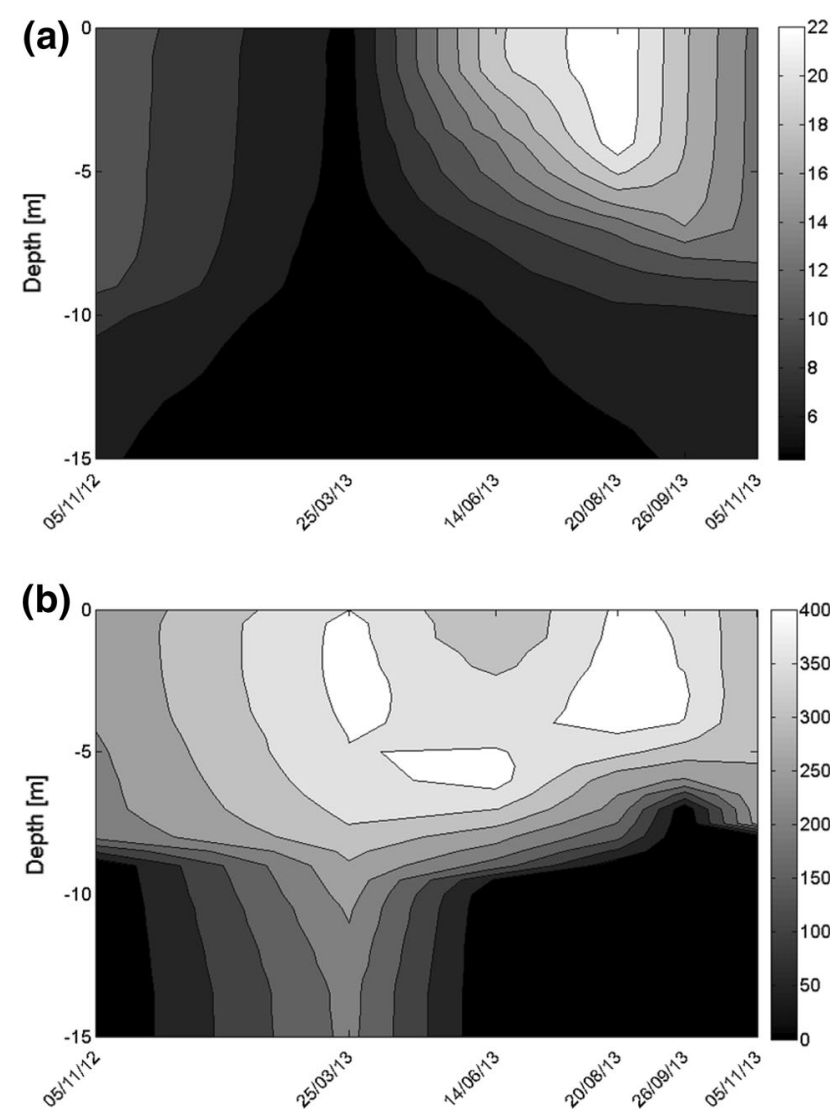

Fig. 7 Annual cycle of temperature (a) and oxygen (b) observed between 2012 and 2013. The dates indicate the days of profile recording (Robert Lovas, pers. communication) 
(a) Conductivity [ $\left.\mu \mathrm{S} \mathrm{cm}^{-1}\right]$

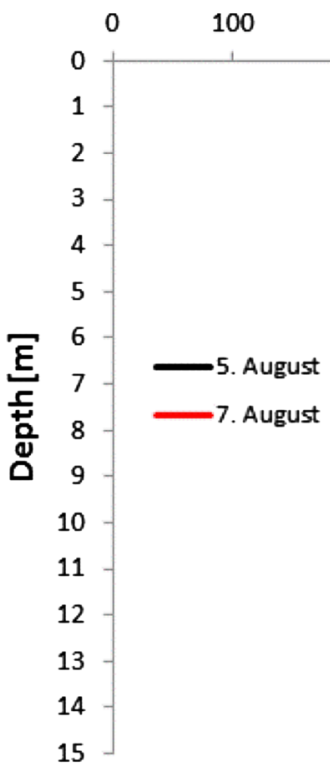

(c)

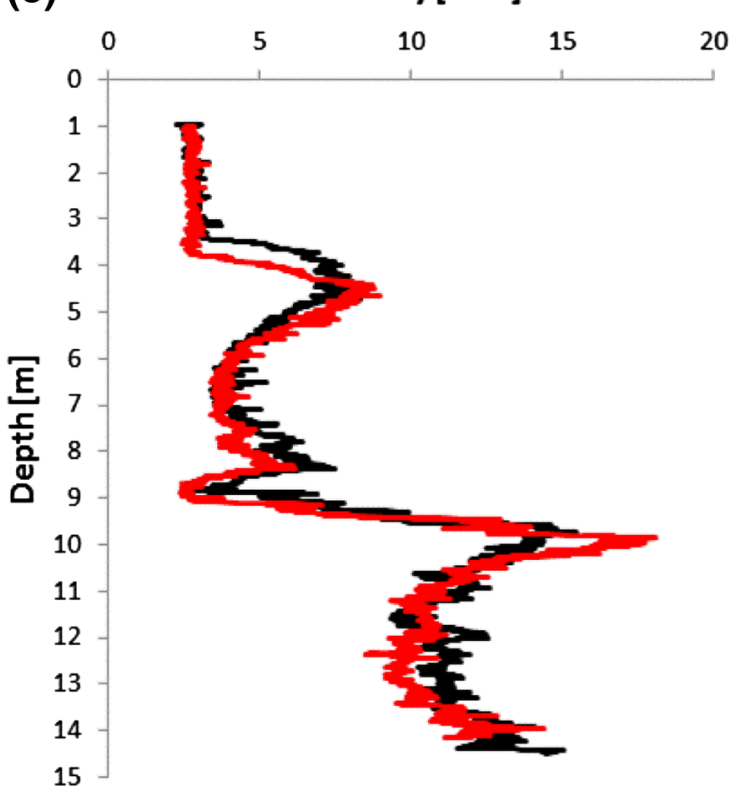

(b)

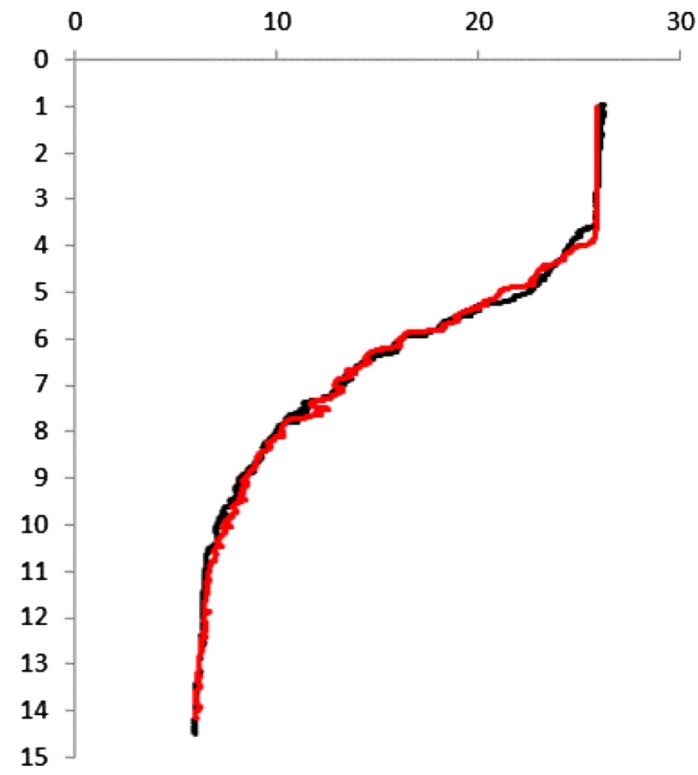

(d) Oxygen [ $\left.\mu \mathrm{mol} \mathrm{I}^{-1}\right]$

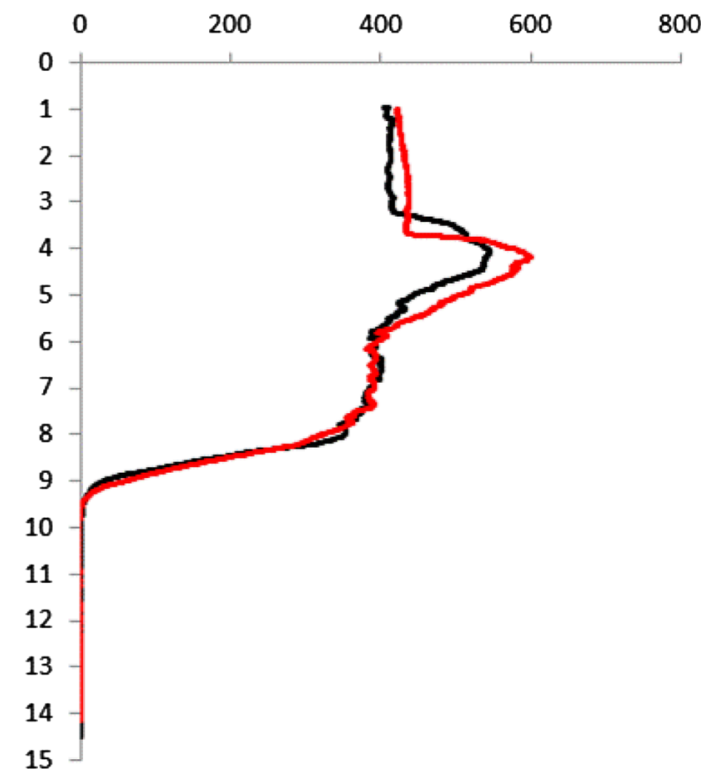

Fig. 8 Comparison of highly resolved parameters measured at the 5th and 7th of August 
Table 4 June phytoplankton density in in $10^{3}$ cells $1^{-1}$

\begin{tabular}{|c|c|c|c|c|}
\hline \multirow[t]{2}{*}{ Class, genus } & \multicolumn{4}{|c|}{ Depth (m) } \\
\hline & 5.3 & 6.8 & 8 & 11 \\
\hline \multicolumn{5}{|l|}{ Bacillariophyceae } \\
\hline Asterionella & 77 & 6 & 442 & 83 \\
\hline \multicolumn{5}{|l|}{ Cyanophyceae } \\
\hline Anabaena & 0 & 184 & 0 & 138 \\
\hline Aphanizomenon & 303 & 0 & 0 & 0 \\
\hline Planktothrix & 4876 & 7866 & 41,584 & 2622 \\
\hline Pseudanabaena & 0 & 0 & 25 & 1587 \\
\hline \multicolumn{5}{|l|}{ Dinophyceae } \\
\hline Gymnodinium & 0 & 0 & 136 & 0 \\
\hline
\end{tabular}

Only genera with more than 1000 counts are listed
Table 5 August phytoplankton density in $10^{3}$ cells $1^{-1}$

\begin{tabular}{|c|c|c|c|c|c|c|c|}
\hline \multirow[t]{2}{*}{ Class, Genus } & \multicolumn{7}{|c|}{ Depth (m) } \\
\hline & 4 & 8 & 9 & 10 & 11 & 12 & 14 \\
\hline \multicolumn{8}{|l|}{ Bacillariophyceae } \\
\hline Fragilaria & 1989 & 405 & 573 & 1325 & 135 & 292 & 89 \\
\hline \multicolumn{8}{|l|}{ Chlorophyceae } \\
\hline Chlorococcales & 2070 & 46 & 97 & 24 & 52 & 52 & 0 \\
\hline Coelastrum & 19,210 & 4306 & 1697 & 303 & 1619 & 1027 & 331 \\
\hline Kirchneriella & 0 & 87 & 229 & 105 & 290 & 462 & 145 \\
\hline Volvox sp. & 1490 & 161 & 28 & 0 & 0 & 0 & 0 \\
\hline \multicolumn{8}{|l|}{ Chlorobiaceae } \\
\hline Chlorobium & 0 & 0 & 0 & 13,800 & 13,800 & 16,860 & 29,394 \\
\hline \multicolumn{8}{|l|}{ Chromatiaceae } \\
\hline Rhabdochromatium & 0 & 0 & 0 & 0 & 0 & 148 & 5244 \\
\hline \multicolumn{8}{|l|}{ Cryptophyceae } \\
\hline Cryptomonas & 189 & 0 & 552 & 61 & 317 & 120 & 48 \\
\hline Rhodomonas sp. & 202 & 762 & 37 & 2 & 3 & 0 & 0 \\
\hline \multicolumn{8}{|l|}{ Cyanophyceae } \\
\hline Aphanizomenon & 0 & 495 & 51 & 345 & 101 & 51 & 34 \\
\hline Aphanocapsa & 0 & 0 & 0 & 0 & 4485 & 0 & 0 \\
\hline Aphanothece & 920 & 6900 & 16,560 & 1855 & 0 & 4140 & 1380 \\
\hline Merismopedia & 0 & 0 & 0 & 2428 & 3892 & 1242 & 1822 \\
\hline Planktothrix & 0 & 1349 & 1619 & 8694 & 2327 & 6348 & 1180 \\
\hline Phormidium & 0 & 0 & 0 & 9374 & 39,330 & 23,460 & 800 \\
\hline Pseudanabaena & 0 & 0 & 93 & 2023 & 6900 & 690 & 1656 \\
\hline Spirulina & 0 & 0 & 331 & 415 & 1525 & 2015 & 1318 \\
\hline Synechococcus & 0 & 0 & 6072 & 6070 & 10,143 & 10,267 & 15,180 \\
\hline
\end{tabular}

Only genera with more than 1000 total counts are listed

\section{References}

Blees J, Niemann H, Wenk CB, Zopfi J, Schubert CJ, Kirf M, Veronesi M, Hitz C, Lehmann MF (2014) Micro-aerobic bacterial methane oxidation in the chemocline and anoxic water column of deep south Alpine Lake Lugano (Switzerland). Limnol Oceanogr 59:311-324
Bloesch J (1974) Sedimentation and phosphorus balance in Lake Lucerne Horw Bay and in the Rotsee, Switzerland. Schweizerische Zeitschrift fuer Hydrologie 36:71-186

Bossard P, Gammeter S, Lehmann C, Schanz F, Bachofen R, Burgi HR, Steiner D, Zimmermann U (2001) Limnological description of the Lakes Zurich, Lucerne, and Cadagno. Aquat Sci 63:225-249 
Camacho A (2006) On the occurrence and ecological features of deep chlorophyll maxima (DCM) in Spanich stratified lakes. Limnetica 25:453-478

Camacho A, Vicente E (1998) Carbon photoassimilation by sharply stratified phototrophic communities at the chemocline of Lake Arcas (Spain). FEMS Microbiol Ecol 25:11-22

Camacho A, Garciapichel F, Vicente E, Castenholz RW (1996) Adaptation to sulfide and to the underwater light field in three cyanobacterial isolates from Lake Arcas (Spain). FEMS Microbiol Ecol 21:293-301

Camacho A, Vicente E, Miracle MR (2000) Ecolcogy of a deep-living oscillatoria (=Planktothrix) population in the sulphide-rich waters of a Spanish karstic lake. Archiv für Hydrobiologie 148:333-355

Camacho A, Erez J, Chicote A, Florin M, Squires MM, Lehmann C, Bachofen R (2001) Microbial microstratification, inorganic carbon photoassimilation and dark carbon fixation at the chemocline of the meromictic Lake Cadagno (Switzerland) and its relevance to the food web. Aquat Sci 63:91-106

Canfield DE, Jorgensen BB, Fossing $\mathrm{H}$, Glud R, Gundersen J, Ramsing NB, Thamdrup B, Hansen JW, Nielsen LP, Hall POJ (1993) Pathways of organic-carbon oxidation in 3 continentalmargin sediments. Mar Geol 113:27-40

Cline JD (1969) Spectrophotometric determination of hydrogen sulfide in natural waters. Limnol Oceanogr 14:454-458

Cohen Y, Jorgensen BB, Revsbech NP, Poplawski R (1986) Adaptation to hydrogen sulfide of oxygenic and anoxygenic photosynthesis among cyanobacteria. Appl Env Microb 51:398-407

Eller G, Känel L, Krüger M (2005) Cooccurrence of aerobic and anaerobic methane oxidation in the water column of Lake Plußsee. Appl Env Microb 71:8925-8928

Fahnenstiel GL, Schelske CL, Moll RA (1984) In-situ quantum efficiency of lake superior phytoplankton. J Great Lakes Res 10:399-406

Friedrich J, Janssen F, Aleynik D, Bange HW, Boltacheva N, Cagatay MN, Dale AW, Etiope G, Erdem Z, Geraga M, Gilli A, Gomoiu MT, Hall POJ, Hansson D, He Y, Holtappels M, Kirf MK, Kononets M, Konovalov S, Lichtschlag A, Livingstone DM, Marinaro G, Mazlumyan S, Naeher S, North RP, Papatheodorou G, Pfannkuche O, Prien R, Rehder G, Schubert CJ, Soltwedel T, Sommer S, Stahl H, Stanev EV, Teaca A, Tengberg A, Waldmann C, Wehrli B, Wenzhoefer F (2014) Investigating hypoxia in aquatic environments: diverse approaches to addressing a complex phenomenon. Biogeosciences 11:1215-1259

Gachter R, Mares A (1979) Comments on the acidification and bubbling method for determining phytoplankton production. Oikos 33:69-73

Gibson CE (1985) Growth-rate, maintenance energy and pigmentation of planktonic cyanophyta during one-hour light-dark cycles. Brit Phycol J 20:155-161

Goltermann HL, Clymo RS, Ohnstad MAM (1978) Methods for physical and chemical analysis of freshwaters. IBP Handbook No. 8. Blackwell Scientific Publishing, Oxford

Guiry MD, Guiry GM (2013) AlgaeBase. World-wide electronic publication. National University of Ireland, Galway. http://www. algaebase.org. Accessed 19 Aug 2013

Jensen K, Revsbech NP, Nielsen LP (1993) Microscale distribution of nitrification activity in sediment determined with a shielded microsensor for nitrate. Appl Env Microb 59:3287-3296

Kirf M, Dinkel C, Schubert CJ, Wehrli B (2014) Submicromolar oxygen profiles at the oxic-anoxic boundary of temperate lakes. Aquat Geochem 20:39-57

Kirk JTO (1994) Light and photosynthesis in aquatic ecosystems, 2nd edn. Cambridge University Press, Cambridge
Klimant I, Meyer V, Kuhl M (1995) Fiberoptic oxygen microsensors, a new tool in aquatic biology. Limnol Oceanogr 40:1159-1165

Kohler HP, Ahring B, Albella C, Ingvorsen K, Keweloh H, Laczko E, Stupperich E, Tomei F (1984) Bacteriological studies on the sulfur cycle in the anaerobic part of the hypolimnion and in the surface sediments of Rotsee in Switzerland. FEMS Microbiol Lett 21:279-286

Legendre L, Demers S, Yentsch CM, Yentsch CS (1983) The C-14 method-patterns of dark CO2 Fixation and DCMU correction to replace the dark bottle. Limnol Oceanogr 28:996-1003

Lloyd D (2002) Noninvasive methods for the investigation of organisms at low oxygen levels. In: Laskin AI, Bennett JW, Gadd GM (eds) Advances in applied microbiology, vol 51. Elsevier, San Diego, pp 155-183

MacIntyre HL, Kana TM, Anning T, Geider RJ (2002) Photoacclimation of photosynthesis irradiance response curves and photosynthetic pigments in microalgae and cyanobacteria. J Phycol 38:17-38

Marie D, Simon N, Vaulot D (2005) Phytoplankton cell counting by flow cytometry. In: Andersen RA (ed) Algal culturing techniques. Elsevier, San Diego

Milucka J, Kirf M, Lu L, Krupke A, Lam P, Littmann S, Kuypers MMM, Schubert CJ (2015) Methane oxidation coupled to oxygenic photosynthesis in anoxic waters. ISME J 9:1991-2002

Murray AP, Gibbs CF, Longmore AR, Flett DJ (1986) Determination of chlorophyll in marine waters-intercomparison of a rapid HPLC method with full HPLC, spectrophotometric and fluorometric methods. Mar Chem 19:211-227

Oren A, Padan E, Avron M (1977) Quantum yields for oxygenic and anoxygenic photosynthesis in cyanobacterium oscillatoria-limnetica. Proc Natl Acad Sci USA 74:2152-2156

Oswald K, Milucka J, Brand A, Littmann S, Wehrli B, Kuypers MMM, Schubert CJ (2015) Light-dependent aerobic methane oxidation reduces methane emissions from seasonally stratified lakes. PLoS One 10:e0132574

Overmann J, Manske AK (2006) Anoxygenic phototrophic bacteria in the Black Sea chemocline. In: Neretin LN (ed) Past and present water column anoxia. NATO Science Series IV Earth and Environmental Sciences. Springer, Dordrecht, pp 523-541

Raven JA, Kubler JE, Beardall J (2000) Put out the light, and then put out the light. J Mar Biol Assoc UK 80:1-25

Revsbech NP, Larsen LH, Gundersen J, Dalsgaard T, Ulloa O, Thamdrup B (2009) Determination of ultra-low oxygen concentrations in oxygen minimum zones by the STOX sensor. Limnol Oceanogr Methods 7:371-381

Rodhe (1958) The primary production in lakes: some results and restrictions of the $14 \mathrm{C}$-methods. Rapports et Procès-Verbaux des Réunions du Conseil International pour l'Exploration de la Mer 144:122-128

Rudd JWM, Furutani A, Flett RJ, Hamilton RD (1976) Factors controlling methane oxidation in shield lakes-role of nitrogen fixation and oxygen concentration. Limnol Oceanogr $21: 357-364$

Schubert CJ, Lucas FS, Durisch-Kaiser E, Stierli R, Diem T, Scheidegger O, Vazquez F, Mueller B (2010) Oxidation and emission of methane in a monomictic lake (Rotsee, Switzerland). Aquat Sci 72:455-466

Stadelmann P (1980) Der Zustand des Rotsees bei Luzern. MaihofRotsee: Geschichte und Eigenart eines Quartiers. Verlag Quartierverein Maihof, Luzern, pp 54-61

Stal LJ (1995) Physiological ecology of cyanobacteria in microbial mats and other communities. New Phytol 131:1-32

Stolper DA, Revsbech NP, Canfield DE (2010) Aerobic growth at nanomolar oxygen concentrations. Proc Natl Acad Sci USA 107:18755-18760 
Thamdrup B, Dalsgaard T, Revsbech NP (2012) Widespread functional anoxia in the oxygen minimum zone of the Eastern South Pacific. Deep-Sea Res. Part I-Oceanogr. Res Pap 65:36-45

Utermöhl H (1958) Zur Vervollkommnung der quantitativen Phytoplankton-Methodik. Mitteilung der internationalen Vereinigung für theoretische und angewandte Limnologie 9:1-38

Wang YF, VanCappellen P (1996) A multicomponent reactive transport model of early diagenesis: application to redox cycling in coastal marine sediments. Geochim Cosmochim Acta 60:2993-3014

Ward DM, Castenholz RW, Miller SR (2012) Cyanobacteria in geothermal habitats. In: Whitton BA (ed) Ecology of cyanobacteria II-their diversity in space and time. Springer, Dordrecht, pp 39-64 